\title{
FROM MONOTHEISM TO SCEPTICISM AND BACK AGAIN
}

\author{
Kenneth Seeskin*
}

\begin{abstract}
Although it is customary to view monotheism and scepticism as opposite, I want to argue that they are closely related - so closely that if you understand monotheism correctly, you will see that a certain form of scepticism is an inevitable consequence. The key to this connection is to recognize that monotheism is more than a claim about number of God; it is also a claim about the uniqueness or incomparability of God. The latter raises a central question: How do you characterize something that is incomparable to everything else? Looking at Maimonides and Aquinas, I argue that to a great extent, you cannot characterize it. Thus Maimonides concluded that silence is the best praise we can offer to God. While Aquinas tried to avoid such a radical conclusion, even he admitted that the words we use to signify God leave the thing signified incomprehensible. Let us now take the next step. If God is the source of all existence, and God is incomprehensible, then scepticism about existence is unavoidable. In the words of Emmanuel Levinas: "The infinite affects thought by devastating it."
\end{abstract}

It should be clear to anyone who has read the Hebrew Bible in a critical way that monotheism did not emerge all at once and that in many cases it is doubtful whether its major characters would be considered monotheists in our sense of the term. ${ }^{1}$ Ancient traditions, both rabbinic and philosophic, held that Abraham was the first person to reject idolatry and embrace monotheism. ${ }^{2}$ The truth is, however, that the Bible has very little to say about Abraham's theology except that he trusted in God and was accounted righteous as a result (Genesis 15:6). But as anyone can see, to trust in God is not to say that God is the only deity. For all we know, Abraham thought there were other gods who, though not as reliable as his, are still forces to be reckoned with.

Much the same could be said of Moses. While the Second Commandment tells us that there should be no other gods before $\mathrm{YHWH}$, it is unclear whether this means that the other gods are not as important as YHWH or that they are nothing but figments of the human imagination. By the same token, the fact that one cannot make or serve an image of God leaves open the question of whether it is impossible to represent an immaterial God in plastic form or whether it is possible but conflicts with how God wants to be worshipped.

Recently the biblical scholar Benjamin Sommer wrote that the evidence that the God of the Hebrew Bible has a body is overwhelming. ${ }^{3}$ In fact, according to Sommer: "God has many bodies located in sundry places in the world that God created." If God does have a body, then there is no reason why a person could not represent God in plastic form if God were to allow it. Even a casual reader of the Bible knows that it does not hesitate to

\footnotetext{
* Klutznick Professor of Jewish Civilization at Northwestern University. Email: k-seeskin@northwestern.edu

${ }^{1}$ For further treatment of some of the issues discussed in this essay, see Kenneth Seeskin, "What the Hebrew Bible Can/Cannot Teach us About God," in Imagining the Jewish God, ed. Kenneth Koltun-Fromm and Len Kaplan, (Lanham, MD: Rowman and Littlefield, forthcoming), and Kenneth Seeskin, "No One can See My Face and Live," in Negative Theology as Jewish Modernity, ed. Michael Fagenblat (Bloomington: Indiana University Press, forthcoming).

2 Genesis Rabbah, §38:13; Josephus, Jewish Antiquities, Book I, §§154-68, 77-81; Philo, “On Abraham,” §\$69-71.

${ }^{3}$ Benjamin D. Sommer, The Bodies of God and the World of Ancient Israel (New York: Cambridge University Press, 2009), 1 .
} 
describe God in anthropomorphic terms. At Exodus 24:10, it goes so far as to say that the elders of Israel actually saw God. The question we must ask is whether the original audience would have followed later traditions in viewing this language as metaphorical or whether they would have understood it literally.

Most bible scholars, including Sommer, assume that the more literal we are, the closer we are to how the original audience would have responded. The reason for this is that the original audience knew nothing of philosophy and the lengths to which later generations would go to bring the Bible into conformity with strict monotheism. But lack of training in philosophy is one thing, literal interpretation of epic narratives, dream scenes, and poetry quite another.

My own suspicion is that people who claim to know how audiences in the ancient Near East would have understood what are by any estimation colourful and highly ambiguous passages are overreaching themselves. Even today, with well-established historical methods at our disposal, we have difficulty determining how literally or loosely legal documents, ethical codes, or training manuals should be interpreted. For example, the First Amendment to the US Constitution prohibits Congress from abridging freedom of speech. Should "speech" be interpreted narrowly to mean verbal communication or broadly to include such things as photography, dance, or music? Similarly, any ethical code will tell you that lying is immoral. Must one make a verbal utterance to lie or could one lie with a hand gesture, facial expression, or bodily movement? Even in natural science, often regarded as the pinnacle of literal discourse, metaphorical language, e.g. atom, cell wall, or big bang, is common.

That the original audience for the Bible was not monotheistic in our sense of the term is hardly controversial. But this too leaves open an important question: Is the reason that they were not monotheistic in our sense of the term that they had a predilection to literal understanding of literary texts or is it rather that the meaning and implications of monotheism were not yet clear to them?

One reason to opt for the latter is the ambiguity in the language that the Bible uses to talk about God. This is particularly true of words like "spirit" (ruach), "glory" (kavod), and "name" (shem). What does it mean to say that the spirit of God hovered over the face of the waters? Is it that God himself was physically present, that a manifestation of God was present, or that God was mindful of the amorphic state of the waters? What does it mean to say that the whole earth is full of God's glory? Is God's glory a synonym for God himself, a blazing light that emanates from God, a mask or shield that protects people from the light, or a way of referring to the honour or respect that is due to God? Unfortunately, biblical Hebrew gives us no reliable way to answer these questions.

A similar ambiguity applies to God's name. Granted that anyone who shows disrespect for God's name shows disrespect for God himself; the precise nature of the relation between the name and the bearer is never made clear. While Psalm 145.21 ("All creatures shall bless his holy name forever and ever") implies that God and his name are one, Deuteronomy 26.2 ("You shall go to the place where the LORD your God will choose to establish his name") implies that they are separate.

Our inability to answer these questions with any degree of certainty testifies to the fact that the language needed to give a precise definition of monotheism had yet to be developed. The distinctions between substance, essence, and accident were not worked out until Aristotle. The concept of a hypostasis did not arise until Plotinus. To impose this 
terminology on biblical discourse would be to engage in an egregious form of anachronism. Again, while the original audience knew that YHWH did not want to be worshipped by having people bow down to plastic representations, it is far from clear that anyone knew or even asked the question of why.

From a modern perspective, the first person to see what strict monotheism required may have been Second Isaiah, a prophet thought to have flourished around the time that Babylonia fell to the Persians in 539 BCE. I say this because it is Second Isaiah who raises the question: "To whom will you liken me that I should be compared?" If mighty armies, the cedars of Lebanon, and the great nations of the world are not suitable comparisons, what is? The obvious answer is nothing. Next to God, everything is as nothing.

It is from this insight that we derive the claim that there is more to monotheism than belief in a single deity. Or, to put it another way, there is a principled difference between monotheism and monolatry. Not only is YHWH the only deity there is, but he is unique in the sense that nothing else resembles him or can stand as a rival to him. In simple terms, God is perfect or absolute, conditioned by nothing. In addition to ruling out a god who yields to natural forces like wind or rain, this view rules out one who faces anything in the way of restriction or limitation. Hermann Cohen expressed this as the difference between einheit and einzigkeit. ${ }^{4}$

With this distinction in mind, we are in a position to ask what I take to be the central question of any monotheistic religion: How do you characterize something that is unique? Since all comparisons are ruled out from the beginning, it will not do to say that God is a bigger, better, or more exalted version than something else. Nor will it do to put God in a category to which something else belongs. How, then, can we say anything substantive about God?

Medieval philosophers like Maimonides and Aquinas tried to answer this question by making a principled distinction between what God is and that God is. Although we can achieve a reasonable degree of certainty about the latter, according to them, we can achieve no certainty about the former. This means that in proving the existence of God, we cannot start with knowledge of God but must start instead with knowledge of the creatures God has brought into being.

In scholastic terms, it means that in proving the existence of God, we have to rely on a demonstration quia rather than a demonstration propter quid. ${ }^{5}$ We reason from the nature of the effect to the existence of the cause. But such an inference does not reveal anything about the nature of the cause except perhaps that it does not need a cause of its own. In Aristotelian terms, this would be a demonstration of the fact (to hoti) rather than a demonstration of the reasoned fact (to dioti).

While the Bible does not advance a systematic theology, it takes notice of God's uniqueness at Exodus 33:20, when God tells Moses that no one can see his face and live.

Both Maimonides and Aquinas took Exodus 33:20 as a parable whose purpose is to express the fact that God's essence is unknowable. ${ }^{6}$

\footnotetext{
${ }^{4}$ Hermann Cohen, "Einheit oder Einzigkeit Gottes," in Judische Schriften, vol. I, ed, Bruno Strauss (Berlin: C.A. Schwetschke \& Sohn, 1924), $87 \mathrm{ff}$.

${ }^{5}$ See Aquinas, Summa Theologica, §1.2.2. Cf. Maimonides, Guide of the Perplexed, §1.34, 74 All references and quotations from Maimonides' Guide of the Perplexed are taken from the translation by Shlomo Pines (Chicago: University of Chicago Press, 1963).

${ }^{6}$ Maimonides, Guide of the Perplexed, §1.54, 123-128. Also see Aquinas, Summa Theologica \$1.12.11.
} 
Their argument for the unknowability of God rests on the claim that God is not susceptible to definition. According to Aristotle, definition proceeds by genus and specific difference. If God cannot be conditioned by anything, then there is no wider category under which God can be subsumed and therefore no possibility of a cause prior to God as living thing is prior to mammal. If no definition can be given of God, then God's essence is beyond our comprehension - at least in this life. ${ }^{7}$

In addition to the logical reason for why we cannot know the essence of God, there is also an epistemological one. According to Maimonides, matter is a strong veil that prevents us from apprehending things that are separate from matter as they truly are. ${ }^{8}$ In like manner, Aquinas maintains that the mode of knowledge follows the mode of the nature of the knower. Because in this life, our soul has its being in corporeal matter, it knows naturally only what has a form in matter or can be known by such a form. ${ }^{9}$ It follows that in this life, there is no natural way for the soul to grasp the nature of God. In fact, both Maimonides and Aquinas compare the human attempt to know God with looking directly at the sun, and conclude that the result would be blindness. ${ }^{10}$

Unlike Aquinas, Maimonides goes further, arguing that the terms we use to describe God, e.g. "wise" or "lives," are completely equivocal so that their meaning when applied to God has nothing in common with their meaning when applied to us. ${ }^{11}$ This is another way of making Isaiah's point: Who would be so bold as to claim that his knowledge, goodness, or power is comparable to God's? Maimonides concludes that when applied to God in a sense in which we can understand, words like "wise," "lives," or "is good" are not just false but categorically so.

For Maimonides the effort to say anything substantive about the nature of God is misguided and bound to end in failure. Quoting the 65 $5^{\text {th }}$ Psalm ("Silence is praise to Thee"), he concludes that the best we can do is to recognize the limits imposed by human discourse and say nothing. ${ }^{12}$ To the question "How can you characterize something that is unique?" his answer is that, in the last analysis, you cannot.

It is well known that Aquinas tried to soften the blow of Maimonides' conclusion by introducing a distinction between the perfections signified and the mode or manner of their signification. ${ }^{13}$ The crux of this distinction is that it allows us to say that words such as "wise," "lives," or "is good" refer to God in a preeminent fashion so that we do not have to remain silent. We can speak of God and know that our words refer correctly. But as to what the nature of divine wisdom, life, or goodness are, and how they are united, we remain in the dark. For Aquinas too, anything we say about God leaves the thing signified "uncomprehended." As he puts it: we are "united to Him as to one unknown." 14

\footnotetext{
${ }^{7}$ The qualification "in this life" is necessary because Aquinas thought the blessed would see God in the next life. Maimonides makes no such concession.

${ }^{8}$ Maimonides, Guide of the Perplexed, §3.9, 436-437.

${ }^{9}$ Aquinas, Summa Theologica, $\$ 1.12 .11$.

${ }^{10}$ Maimonides, Guide of the Perplexed, §1.59; Aquinas, Summa Theologica, §1.12.1.

${ }^{11}$ Maimonides, Guide of the Perplexed, $\$ 1.56,131$.

${ }^{12}$ Compare with Plotinus, Enneads, $\$ 5.5 .6$, who says that there are times when silence contains more truth than speech.

${ }^{13}$ Aquinas, Summa Theologica, §1.13.3.

${ }^{14}$ Aquinas, Summa Theologica, §1.12.13.
} 
The only exception that Maimonides and Aquinas recognize is the Tetragrammaton (YHWH), the proper name of God as revealed at Exodus 3:14. ${ }^{15}$ Etymologically the Tetragrammaton is derived from the Hebrew verb to be (hayah) so that when Moses asks God the name of the one who has sent him, God says: "I AM WHO I AM. Tell the Israelites: I AM has sent me to you." Maimonides interprets the passage to mean that the subject is identical with the predicate rather than an attribute added to it. In his words: "This name is not indicative of an attribute but of simple existence and nothing else." Aquinas, who did not read Hebrew but trusted Maimonides on how to make sense of the passage, followed suit.

Can we say, then, that simple or necessary existence constitutes the essence of God? The answer is: Not without a significant qualification. Recall that for Maimonides, the meaning of terms when applied to God has nothing in common with their meaning when applied to us. In his opinion, this applies as much to "exist" as it does to "wise" or "lives." If this is true, then simple or necessary existence has no positive content that we can understand. While the Tetragrammaton names God by means of necessary existence, it leaves us completely in the dark as to what the nature of that existence is. To paraphrase Aquinas, though simple or necessary existence may be meaningful to God, for us it is anything but.

It is clear, then, that while both thinkers constructed elaborate theological systems, these systems accommodate a good deal of unknowing. In my view, this is not accidental. To see why, let us return to pagan gods, which is to say gods who are comparable to other things. Once such comparisons are allowed - once we identify spheres of influence over which the gods have sway, know where they reside, what they do during the day, and how they can be appeased - any element of mystery is greatly reduced. For all intents and purposes, the gods become superheroes analogous to the characters that appear in comic books. This impression is heightened if, like the Greek gods and goddesses, they lust after mortals and create a class of beings who are half mortal and half immortal.

The price monotheism paid for rejecting the pagan worldview is that it put severe limits on what we can know about God. We can know the world God created but we cannot know anything about the nature of the creator. In the words of Exodus 33, we can see the "backside" of God but not the "face" of God, where the backside refers to the moral qualities revealed in the next chapter: mercy, graciousness, slowness to anger, and willingness to forgive sin. But, Maimonides insists, rather than moral dispositions that inhere in God, these qualities are features of the natural order that God brought into being and proclaimed "very good" at Genesis $1.31 .{ }^{16}$ God himself remains a simple, unchanging being whose internal nature is unknown to us.

Even if one were to look beyond the great systems of the middle ages, one would find that Isaiah's question "How do you characterize something that is unique?" still played an important role in religious thought. According to Descartes, if God is conditioned by nothing, then God cannot be constrained by the laws of mathematics. In a famous letter to Mersenne, he writes:

The mathematical truths which you call eternal have been laid down by God and depend on Him entirely no less than the rest of his creatures ... Indeed to say that these truths are

\footnotetext{
${ }^{15}$ For Maimonides' analysis of the Tetragrammaton, see Maimonides, Guide of the Perplexed, \$1.61, 147-150.

${ }_{16}$ Maimonides, Guide of the Perplexed, $\$ 1.54,125-126$.
} 
independent of God is to talk of Him as if He were Jupiter or Saturn and to subject Him to the Styx and the Fates. ${ }^{17}$

The typical scholastic position was that the eternal truths are inherent in the nature of things and do not result from a free choice of God. ${ }^{18}$ Descartes' point is that such a view amounts to a return to paganism because it subjects God to a greater power. As he says in a letter to Mesland, the power of God cannot have any limits at all. ${ }^{19}$

If God's power cannot have any limits, then it will not do to say that rational thought imposes any restriction on God. For all we know, God is indifferent to the principles of thought that we hold dear or even contemptuous of them. Could God make a triangle whose internal angles equal less or more than 180 degrees? Although we cannot understand how such a thing could be, if Descartes is right, that gives us no grounds for saying what God can or cannot do.

A similar position is taken by Kierkegaard in Fear and Trembling. As far as we are concerned, the sacrificial murder of an innocent child is an atrocity. The Book of Deuteronomy (12:31 \& 18:9-12) says as much. How, then, can God command Abraham to sacrifice Isaac? How can he transform what he himself has labelled an atrocity into a holy act? Or to put it another way, by what right can God claim an exception to one of the most basic moral rules we can imagine? The answer is that if God is absolute, conditioned by nothing, then God can do whatever he wants - even if what he does strikes us as absurd.

Once again we are left with the conclusion that rational thought may have no purchase on God. If this is right, then the degree of unknowing envisioned by Maimonides and Aquinas has expanded to the point where it encompasses practically every intuition we have. If God can do anything he wants and make anything he wants, then whatever we say about God could be true or false depending on what God has decreed. If whatever we say could be true or false, then a healthy dose of scepticism, either moral or epistemological, is unavoidable.

This point was not lost on Hume, one of the greatest sceptics of all. In the Dialogues Concerning Natural Religion, he has Cleanthes object that if Demea's conception of God is right, then:

... if our ideas, so far as they go, be not just and adequate, and correspondent to his real nature, I know not what there is in this subject worth insisting on. Is the name, without any meaning, of such importance? Or how do you MYSTICS, who maintain the absolute incomprehensibility of the Deity, differ from sceptics or atheists, who assert that the first cause of ALL is unknown and unintelligible? ${ }^{20}$

At a rudimentary level, Maimonides and Aquinas are saying that we can know that a first cause of ALL exists. Not every thinker would admit this. In fact, it is doubtful that Hume would.

But Cleanthes' question still has force. How does such a rigorous form of monotheism differ from scepticism and atheism? If scepticism means taking a critical attitude toward all

\footnotetext{
${ }_{17}$ Descartes: Philosophical Letters, ed. Anthony Kenny (Oxford: Clarendon Press, 1970), 18-9.

${ }^{18}$ See, for example, Maimonides, Guide of the Perplexed, §3.15, 459-461.

${ }^{19}$ Descartes: Philosophical Letters, 15.

${ }^{20}$ David Hume, Dialogues Concerning Natural Religion, 2nd ed. (Indianapolis: Hackett Publishing, 1998), 28.
} 
of one's beliefs, not claiming more for one's arguments than they actually show, and remaining open to alternative arguments, the simple answer is that they do not differ. According to Maimonides:

For if you stay your progress because of a dubious point; if you do not deceive yourself into believing that there is a demonstration with regard to matters that have not been demonstrated; if you do not hasten to reject and categorically to pronounce false any assertions whose contradictories have not been demonstrated; if, finally you do not aspire to apprehend that which you are unable to apprehend - you will have achieved human perfection and attained the rank of Rabbi Akiba ${ }^{21}$

The reference to Akiba comes from the famous parable in which four rabbis were permitted to enter "a realm of secrets" (pardes), which is normally taken to mean that they were introduced to esoteric subjects. ${ }^{22}$ With a single exception, the results were damaging: one went mad, one killed himself, and one became an apostate. Of the four, only Akiba went in and came out in peace. The lesson Maimonides draws from this is that of the four, only Akiba recognized his limits and stayed within them.

This does not mean that we should question everything from the existence of an external world to that of other minds. Rather it means that when we are dealing with theological questions like the nature of God or the creation of the world, we should proceed with caution and not go beyond the limits that the human condition imposes on us. Maimonides would therefore agree with Hume that without the chance to make careful measurements and observations of the things we are talking about, our opinions are more speculation than knowledge. When it comes to astronomy, for example, he argued that most of the Aristotelian system amounted to nothing more than guesswork and conjecture. ${ }^{23}$

Where he would disagree with Hume is over the significance of the claim: "There is a first cause of the universe." As the first paragraph of the Mishneh Torah makes clear, Maimonides does not see this as an isolated claim but as the pillar on which to construct an entire worldview. If there is a first cause, then in his opinion, there is a systematic order to everything that is. The highest human achievement is to recognize the existence of that order and one's proper place within it. When this happens, the result will be a complete transformation in how a person lives his life. Thus:

When a man reflects on these things, studies all these created beings, from the angels and spheres down to human beings and so on, and realizes the divine wisdom manifested in them all, his love for God will increase, his soul will thirst, his very flesh will yearn to love God. He will be filled with fear and trembling, as he becomes conscious of his lowly condition, poverty, and insignificance, and compares himself with any of the great and holy bodies; still more when he compares himself with any one of the pure forms that are incorporeal and have never had association with any corporeal substance. He will then realize that he is a vessel full of shame, dishonor, and reproach, empty and deficient. ${ }^{24}$

\footnotetext{
${ }^{21}$ Maimonides, Guide of the Perplexed, §1.32, 68-70.

22 The reference is to Chagigah $14 \mathrm{~b}$.

${ }^{23}$ Maimonides, Guide of the Perplexed, §2.22, 319-320.

${ }^{24}$ Maimonides, "Principles of the Torah," Mishneh Torah I, §4.12.
} 
The assumption behind this passage is that if one considers the vastness and majesty of the universe and the fact that everything springs from a single cause, they will see the vanity and pettiness in most of the things that people care about. As Job came to see, popularity, wealth, power, even physical health, are not really important. In the end, nothing compares to the ability to achieve a global and eternal perspective on the universe.

While modern readers may be put off by the idea that we are nothing but vessels full of shame, dishonour, and reproach, we should keep in mind that Maimonides is talking about our station in comparison with everything else. Rather than the high point of creation, we are at most a tiny part. From this recognition, it is but a small step to the honesty and humility that Maimonides associates with Akiba.

How do we get to such a point? If we look at the recommendations of those who have completed the journey - in other words, the record of prophetic and rabbinic literature then we will see that this is exactly what the commandments of the Torah are designed to do. While it may not be obvious at first how refraining from eating pork or wearing garments made of wool and flax help to accomplish this, the 14 volumes of the Mishneh Torah constitute Maimonides' answer. At a rudimentary level, the commandments are intended to subdue the material dimension of human existence. At a more exalted level, they ask us not only to admit to the existence of a first cause but to love it in a way that both anticipates and lays the groundwork for Spinoza's amor Dei intellectualis.

Such a love seeks nothing in the way of a material reward, a personal afterlife, or a reciprocal response from God - only the satisfaction that comes with knowing that one has reached the highest level the human intellect can achieve, which is to say that for Maimonides one has attained the only thing in life that is valuable as an end in itself. To those who think this is a religion manqué, the answer is that this is what true monotheism requires. The God who is incomparable to anything else becomes an object of love that is incomparable to any other. Emmanuel Levinas once wrote that a religion like this always runs the risk of atheism..$^{25}$ Take away any material reward, personal afterlife, or reciprocal response from God, and most people will say that it is not a religion at all.

Here it is worth noting that as enlightened a figure as Kant considered Spinoza an atheist, and that Maimonides' works were burned by the rabbis of Southern France. But to continue with Levinas, the risk is one we have to take. God is not our friend or our personal protector. He is nothing more and nothing less than what strict monotheism claims that he is: the first cause of the universe and a being incomparable to any other. For a person who is committed to monotheism, that is quite enough.

\section{BIBLIOGRAPHY}

Cohen, Hermann. "Einheit oder Einzigkeit Gottes." In Judische Schriften, vol. I, edited by Bruno Strauss. Berlin: C.A. Schwetschke \& Sohn, 1924.

Descartes, Rene. Philosophical Letters. Edited by Anthony Kenny. Oxford: Clarendon Press, 1970.

${ }^{25}$ Emmanuel Levinas, Difficult Freedom: Essays on Judaism, trans. Sean Hand (Baltimore: Johns Hopkins Press, 1990), 15. 
Hume, David. Dialogues Concerning Natural Religion. $2^{\text {nd }}$ ed. Indianapolis: Hackett Publishing, 1998.

Josephus, Flavius. Jewish Antiquities. Book I. Translated by J. Thackery. Cambridge: Harvard University Press, 1930.

Levinas, Emmanuel. Difficult Freedom: Essays on Judaism. Translated by Sean Hand. Baltimore: The Johns Hopkins University Press, 1990.

Maimonides, Moses. Guide of the Perplexed. Translated by Shlomo Pines. Chicago: University of Chicago Press, 1963.

- Mishneh Torah. Translated by E. Touger. New York and Jerusalem: Moznaim Publishing, 1989.

Philo. "On Abraham." Loeb Classical Library. Vol. VI. Translated by F. H. Colson. Cambridge: Harvard Univ. Press, 1935.

Seeskin, Kenneth. "What the Hebrew Bible Can/Cannot Teach us About God." In Imagining the Jewish God, edited by Kenneth Koltun-Fromm and Len Kaplan. Lanham, MD: Rowman and Littlefield, forthcoming.

—. "No One can See My Face and Live." In Negative Theology as Jewish Modernity, ed. Michael Fagenblat. Bloomington: Indiana University Press, forthcoming.

Sommer, Benjamin, D. The Bodies of God and the World of Ancient Israel. New York: Cambridge University Press, 2009. 